\title{
Developing Authentic Assessment for Reading Competence
}

\author{
Hazairin Eko Prasetyo \\ Sarjanawiyata Tamansiswa University, Yogyakarta \\ hazekpras@yahoo.com
}

\begin{abstract}
The purpose of this paper is to describe how language teachers in Indonesia can independently develop an authentic assessment for measuring their students' reading competence. This is a high priority in terms of two reasons: 1) in the era of globalisation, teachers can no longer rely on traditional approaches (Djiwandono, 2011) in testing their students' reading competence due to the fact that the students are supposed to be able to take part in international reading competition like PISA and PIRLS whose test items are developed from authentic texts, and 2) authentic assessment is more relevant with daily communication needs and professional development. Therefore, the focus of discussion would be given to various concepts of authentic assessment for reading competence.
\end{abstract}

Keywords: authentic assessment, reading competence

\section{INTRODUCTION}

The importance of students' reading competence in Indonesia is, for instance, shown by the government by assigning the administration of PISA (Program for International Student Assessment) to the Ministry of Education and Culture. PISA itself is organised by OECD (the Organisation for Economic Co-operation and Development) and Indonesia, since its initial participation in 2000, has got lower ranks in reading, mathematics and science literacies. The following table shows Indonesian position in PISA (Litbangkemdikbud, 2016) from 2000 to 2009.

\begin{tabular}{|c|c|c|c|c|c|}
\hline $\begin{array}{l}\text { Yea } \\
\mathrm{r}\end{array}$ & Subject & $\begin{array}{l}\text { Indonesi } \\
\text { an } \\
\text { average } \\
\text { score }\end{array}$ & $\begin{array}{l}\text { Internatio } \\
\text { nal } \\
\text { average } \\
\text { score }\end{array}$ & $\begin{array}{l}\text { Indonesi } \\
\text { an rank }\end{array}$ & $\begin{array}{l}\text { Number } \\
\text { of } \\
\text { participati } \\
\text { ng } \\
\text { countries }\end{array}$ \\
\hline \multirow{3}{*}{$\begin{array}{l}200 \\
0\end{array}$} & Reading & 371 & 500 & 39 & \multirow{3}{*}{41} \\
\hline & $\begin{array}{l}\text { Mathemati } \\
\text { cs }\end{array}$ & 367 & 500 & 39 & \\
\hline & Science & 393 & 500 & 38 & \\
\hline \multirow{3}{*}{$\begin{array}{l}200 \\
3\end{array}$} & Reading & 382 & 500 & 39 & \multirow{3}{*}{40} \\
\hline & $\begin{array}{l}\text { Mathemati } \\
\text { cs }\end{array}$ & 360 & 500 & 38 & \\
\hline & Science & 395 & 500 & 38 & \\
\hline \multirow{3}{*}{$\begin{array}{l}200 \\
6\end{array}$} & Reading & 393 & 500 & 48 & 56 \\
\hline & $\begin{array}{l}\text { Mathemati } \\
\text { cs }\end{array}$ & 391 & 500 & 50 & \multirow[t]{2}{*}{57} \\
\hline & Science & 393 & 500 & 50 & \\
\hline \multirow{3}{*}{$\begin{array}{l}200 \\
9\end{array}$} & Reading & 402 & 500 & 57 & \multirow{3}{*}{65} \\
\hline & $\begin{array}{l}\text { Mathemati } \\
\text { cs }\end{array}$ & 371 & 500 & 61 & \\
\hline & Science & 383 & 500 & 60 & \\
\hline
\end{tabular}

Table 1. Indonesian position in PISA's survey among participating countries

The results of the survey show that there must be more serious efforts among Indonesian teachers, especially those teaching English, mathematics and science at junior high schools for the survey is done to fifteen years old students, to be more accustomed to authentic teaching materials as well as authentic assessment.

Indonesian participation in PIRLS (Progress in International Reading Literacy Study) organised by the International Association for the Evaluation of Educational Achievement has not yet shown satisfactory results. In 2006, for example, with the average score of 405 from international score of 500 , this country ranked 41 of 45 participanting countries. In 2011, it ranked 45 from 46 participating countries under international benchmark for reading (Mullis, Martin, Foy \& Ducker, 2012). For the fourth administration in 2016, as PIRLS is held once in five years, 54 countries, including the United States will take part in the 2016 PIRLS cycle. In the cycle, there is some improvement in the administration of the survey, which is the use of an innovative assessment of online reading called ePIRLS (Progress in international reading literacy study, 2016). Again, it is a very challenging situation for elementary school teachers in Indonesia to administer PIRLS cycle among the fourth grade students.

Although challenging, it is important to have authentic assessment. Some studies have been conducted in relation to authentic assessment (Ebrahimzadeh, 2016; Sağirli, 2016; Ebadi \&Saeedian, 2016). The siginificance of authentic assessment for reading competence is shown in an experimental study of portfolio assessment for reading classes in Iran (Ebrahimzadeh, 2016). In the study, there was a siginificant difference in performance between the subjects belonging to the experimental group with portfolio assessment and those belonging to the control group with traditional assessment. Besides that, the learning of reading and writing by using the sentence method was investigated (Sağirli, 2016). The results of the study showed that the subjects were more successful in doing multiple-choice questions than open-ended questions. Another study was done (Ebadi \& Saeedian, 2016) to find out how computerised dynamic assessment influenced reading comprehension among the respondents. The results of the studies showed the importance of authentic assessment in its various forms. 
However, there are problems among Indonesian English language teachers to develop their own authentic assessment because so far they are not accustomed to preparing test items for assessing authentic materials. This was shown from the observation on the high school English teachers participating in Pendidikan dan Latihan Profesi Guru (teachers' professional development inservice training) from 2007 to 2015. Most of them had a difficulty preparing their own test items and they just copied from existing books and used them for assessing their students. Thus, the problem to be addressed in this paper is how English language teachers in Indonesia develop their own authentic asssessment for reading competence.

\section{THEORETICAL BACKGROUND}

\subsection{Authentic assessment}

What is meant by authentic assessment should be made clear from a comparison with what traditional teachers did in the past when they tested their students. Most of them defined a test in terms of an exercise the students had to do by writing the answers to the questions on a piece of paper. Hancock (2006) lists six elements which differentiate a traditional test from an authentic assessment as follows.

\begin{tabular}{llll}
\hline No. & Aspect & $\begin{array}{l}\text { Traditional } \\
\text { test }\end{array}$ & $\begin{array}{l}\text { Authentic } \\
\text { assessment }\end{array}$ \\
\hline a. & $\begin{array}{l}\text { Students } \\
\text { preparation }\end{array}$ & $\begin{array}{l}\text { Yes, it is } \\
\text { announced } \\
\text { before. }\end{array}$ & $\begin{array}{l}\text { No, it is not } \\
\text { announced } \\
\text { before. }\end{array}$ \\
\hline b. & Focus & $\begin{array}{l}\text { Students' } \\
\text { achievement. }\end{array}$ & $\begin{array}{l}\text { Students' } \\
\text { progress. }\end{array}$ \\
\hline c. & Result & Score or grade. & Monitoring. \\
\hline d. & Frequency & $\begin{array}{l}\text { Regularly } \\
\text { planned. }\end{array}$ & $\begin{array}{l}\text { Random and } \\
\text { continuous. }\end{array}$ \\
\hline e. & Format & $\begin{array}{l}\text { Multiple } \\
\text { choice test, } \\
\text { True or False, } \\
\text { completion, } \\
\text { etc. }\end{array}$ & $\begin{array}{l}\text { Observation } \\
\text { sheet, } \\
\text { portfolio, tasks, } \\
\text { etc. }\end{array}$ \\
\hline f. & Context & $\begin{array}{l}\text { Frequently } \\
\text { contextualised. }\end{array}$ & $\begin{array}{l}\text { Mostly } \\
\text { contextualised. }\end{array}$ \\
\hline
\end{tabular}

An authentic assessment is based on the students' actual activities which represent, and are needed in, real life situations (Svinicki, 2004). As such is different from a traditional approach in assessing students' learning. Wiggins (1998), in this case, mentions six criteria of an authentic assessment:

a. Realistic, that is the test shows how the information to be retrieved or skills to be shown would be used in an actual situation or world of work;

b. Open to possible alternatives, i.e. the answer to a question requires judgment and innovation and, thus, it is possible for the students to provide alternative answers; c. Performing, that is when the students have to do a certain number of steps specific in a field of study;

d. Contextual, i.e. the situation of the assessment is close to the actual context in which the related skills or knowledge are to be used;

e. Comprehensive, that is the students are exposed to a situation during the assessment in which they need a variety of approaches or judgments to overcome a complicated problem; and

f. Open to second chance options for feedback and practice to provide a solution of a difficult problem.

One more important factor differentiating traditional from authentic assessments is in its transparency. Unlike the traditional assessment which is closed from the students and is frequently regarded as a secret, an authentic assessment is open as to the materials and how it will be processed for scoring and final grade.

Some examples of authentic assessment include students' portfolio which consists of all the documents showing their evidenced abilities to show how much they make progress in their learning activities (Charvade, Jahandar \& Khodabandehlou, 2012), case studies on real world problems like internships for the student-candidates of teachers who seek for a solution of a particular problem from a lecture while observing what happens at schools, simulated environment (Svincki, 2004) in which students are supposed to act a particular role while the other students are assigned other roles to, for example, create a plan of business; and real products that the students have successfully accomplished. In all those authentic assessments, the teacher must prepare a certain assessment rubric which is especally designed for scoring or measuring the students' achievements.

There are advantages and disadvantages of this kind of assessment. The advantages are mainly for the students including real life situations they face in learning and more open atmosphere in achieving certain level of grades. For the teacher, the advantage is in creating a more relaxing climate among the students, thus he can avoid a stressful kind of assessment. The disadvantages include administration of scores, more works and time for accomplishing a task, more time and concentration for assessing the portfolio, and, if the rubric is not well prepared, scores tend to be more subjective.

The reading assessment process involves the four steps (Caldwell, 2008) as follows.

a. Identification of assessment objects, in this step a teacher needs to define what to assess including their understanding of a text, mastery of vocabulary items, ability to find examples in a particular text, ability to rephrase sentences in their own words, or the ability to just spell particular new entries,

b. Collection of evidence, in this step the teacher is supposed to find and take certain words or 
phrases to be used as key answers to the test items,

c. Analysis of evidence, in this step the teacher tries to describe why a certain word or phrase is true and the others are not to answer existing questions, and

d. Decision making, in this step the teacher has to decide whether he will be using all that he has analysed to be correct answers in scoring the students' performance.

These steps would be very helpful in preparing an authentic assesssment in terms of setting the criteria of scoring including identification of assessment objects, collection of evidence, analysis of evidence, and decision making.

In scoring students' portfolios, it is impossible for a teacher to score everything in the students' written reports of reading assignments collected during a semester. Setting the assessment objects of the reports, for example the levels of the students' understanding of a text and the stages of the students' vocabulary mastery, would help the teachers simplify their scoring process from reading through the whole reports one by one to ticking certain rubrics especially prepared for such a scoring process. If the students' portfolios are also meant to teach the students how to find examples in a particular text, the identification of the assessment object is of a great help, for instance, the students are asked to find out examples of any nominal phrases related to certain settings of the reading text. This is also true when the students are supposed to be able to rephrase sentences in their own words by limiting the kinds of sentences they have to rephrase, for example, they are asked to rephrase all sentences supporting the main ideas of a text in their own words. Another object of assessment deemed to be important in scoring the students' portfolios is spelling particular new entries correctly. Since the number of the new entries of a lengthy text can be more than a hundred, it would be more practical to ask the students to single out the spelling of the new entries in an additional column on the right side of the corresponding sentence or paragraph.

Scoring students' reports of certain case studies is a challenging task for a teacher. Reading word by word through the lines of the reports takes a lot of the teacher's time. Since the students' real task in reading case studies is collecting evidence, the teacher can set up certain types of evidence to be collected from particular cases the students have to read. Therefore, the scoring can be focussed on the evidence of the introductory part of the case, the main body of the case, and the solution ranging from minimal to maximal number of evidence the students could show. The bigger the number of evidence the students could show, the better the score.

Besides the number of evidence, the analysis of the evidence is of great importance in assessing students' reading. However, when portfolios or case studies are used in the assessment, scoring students' analyses of evidence could be more tedious than scoring the collection of evidence itself. One of the possible ways to simplify such a scoring process is by using a classification grid consisting of five levels of analysis related to data supports: very poor, poor, fair, good, and very good. The more evidence the students could show to support their analyses, the better their level of analyses will be.

Decision making is the final step in assessing students' reading assignments. This can be done more easily when it is about one short text, but it could be more complicated when it deals with authentic assessment like portfolio, case studies, simulated environment, and real product. Deciding a student's reading ability from his portfolio containing twelve extensive reading reports in one semester, for instance, is not as simple as deciding a score of a multiple-choice reading test consisiting of twenty items. Therefore, it is helpful to do so by taking the three steps of reading assessment into consideration: the identification of the assessment objects, the collection of evidence, and the analysis of evidence. By using the three stpes as criteria for decision making, a teacher could decide to what level of reading ability his students belong as well as providing arguments for the decision.

\subsection{Reading competence}

The definition of reading competence would include such this as the ability to read a particular text in terms of techniques and understanding that a student possess. There are eight micro skills that a reader must have when reading a text to show that he is a competent reader (Djiwandono, 2011). The eight micro skills are

a. understanding the meanings of words in their contextual structures,

b. understanding the structure of the text and the relations among its parts,

c. being able to identify the explicit main ideas of the text,

d. being able to answer the questions related to the explicit meanings of the text,

e. being able to answer the questions related to certain facts in the text in different words or expressions, and

f. being able to make inferences of the text,

g. being able to identify and understand literary expressions in the text, and

h. being able to identify and understand the writer's intentions and messages.

In the context of international reading survey among the fourth grade students of elementary schools, PISA has decided the 2015 reading literacy framework containing five assessment tasks including

a. retrieving information

b. forming a broad understanding

c. developing an interpretation

d. reflecting on and evaluating the content of a text

e. reflecting on and evaluating the form of a text. 
Meanwhile, PIRLS, which is designed for junior high school students, has also issued its 2016 framework for reading and comprehension purposes as follows.

a. Purposes of reading

- literary experience:

- acquire and use of information

b. Processes of comprehension:

- focus on and retrieve explicitly stated information

- make straightforward inferences

- interpret and integrate ideas and information

- evaluate and critique content and textual elements

These two international frameworks must be used as the guidelines for both English language teachers at junior high schools and the fourth grade teachers of elementary schools in designing their authentic assessment for their students.

\section{DISCUSSION}

\subsection{How to develop authentic assessment for reading} competence

To most English teachers in Indonesia, authentic assessment for students' reading competence is a challenge and opportunity as well. Such an assessment is a challenge because, so far, it is more practicable for them to administer a traditional kind of reading assessment like multiple-choice tests, especially when such tests are already provided in an exercise book for students. They are easy to organize and score. On the other hand, an authentic assessment needs authentic materials which necessitate more efforts and time to prepare. Therefore, when the teachers are supposed to give an extensive reading task to their students, for example, they must select from available sources, especially in the internet, six to eight simplified novels for the students to read during one semester. They must also prepare a particular book report format that could be easily used by their students. A certain rubric of scoring is another preparation that they must make. The most burdensome step that they must carry out is the scoring of the students' reports. When all these things can be done successfully, the teachers have created an opportunity to improve both the quantity and quality of reading among their students.

What the teahers must keep in mind while preparing authentic assessments is the conceptual assumptions behind what reading competence is to the students. Reading competence should be understood to include certain cognitive, affective and psychomotor aspects that learners achieve after following particular lessons. Brown (2007) contrasted competence against performance in terms of their observability. If the knowledge the learners get is observable in the correct pronunciation or intonation of certain utterances after a certain period of learning time, for instance, it is performance. While the underlying knowledge driving that particular correctness in the pronunciation or intonation is referred to as competence.
When English teachers in Indonesia start using authentic assessments for reading competence, especially in the forms of portfolios of extensive reading assignments which are probably not popular among both teachers and students, there is a hope for a better English reading performance and competence at the national level. Therefore, as it is the case in most educational efforts in this country, a formal approach must be implemented to make the hope comes to reality, that is, by assigning all English teachers in Indonesia to use authentic assessments for reading competence, especially by extending the students' interactions with reading materials outside the classrooms, as part of the national curriculum of English language teaching and learning. In such a regulation, there should also be lists of English vocabulary levels and appropriate books for certain grades. The existence of these obligatory assignments for the English teachers would help much in improving what they have been doing so far.

In developing an authentic assessment for improving the students' reading performance and competence in daily activities of teaching reading, not including portfolio assessment, the following steps could be followed.

a. Decide whether the assessment is designed to find out the learners' achievement in reading macroskills, for example differentiating literal from contextual meanings of certain expressions in a text, or microskills, for example recognising a grammatical word class of certain expressions in a text (Brown, 2004).

b. Prepare an instrument for the assessment, for instance an observation sheet containing particular aspects of reading macroskills or microskills to be focussed in an informal assessment activity.

c. To achieve an optimum efficiency, only outstanding phenomena among the learners should be put into the observation sheet because in normal classroom situations in general students tend to be between the two opposing extreme sides, extremely good and extremely bad.

d. Since the main purpose of such an assessment is to improve the reading competence and performance of the students and is not only limited to a score gathering activity, the teacher also prepares follow up learning activities in relation to the results of the assessment.

e. This cycle of assessment should be repeated again and again in such a manner that all the problems to be encountered in the assessment activities are resolved and the students are succeessful in improving their reading competence as well as their reading performance.

The five steps of developing an authentic assessment for improving the students' reading performance and competence above are the most practical implementations of Brown's reading macro and microskills in Indonesian contexts which have been practiced so far excluding the use of the results of the authentic assessment for improving the teaching and 
learning outputs and aoutcomes. Therefore, the five steps must be applied as they are as parts of authentic assessment procedures. It would be much better if action researches are also carried out to find out whether the five steps in developing an authentic assessment for reading competence are conceptually correct and contextually appropriate.

\section{CONCLUSIONS}

Authentic assessment is important for both students and teachers in relation to the developing circumstance of global education which is characterised by the emergence of international surveys to measure the educational indicators of the countries participating in the survey. Therefore, English teachers in Indonesia must be willing to develop their own authentic assessment for students' reading competence. The most important point in developing such an assessment is the possibility of assigning portfolio of extensive reading assignments. By referring to whether the assessment is meant for macro or microskills of reading, there are four aspects of assessments to be taken into consideration including identification of assessment objects, collection of evidence, analysis of evidence, and decision making.

\section{REFERENCES}

Brown, D. H. (2004). Language assessment: Principles and classroom practices. White Plains, New York: Pearson Education.

Brown, D. H. (2007). Principles of language teaching and learning $\left(5^{\text {th }}\right.$ edition). White Plains, New York: Pearson Education.

Caldwell, J. S. (2008). Reading assessment: A premier for teachers and coaches. New York \& London: The Guilford Press.

Charvade, M. R., Jahandar, S., \& Khobahandehlou, M. (2012). The impact of portfolio assessment on EFL learners' reading comprehension ability. English Language Teaching Vol. 5, No. 7, 129-139.

Djiwandono, S. (2011). Tes bahasa: Pegangan bagi pengajar bahasa. Jakarta: PT. Indeks.

Ebadi, S., \& Saeedian, A. (2016). Exploring transcendence in EFL learners' reading comprehension through computerized dynamic assessment. Iranian Journal of Language Teaching Research 4(1), 27-45.

Ebrahimzadeh, M. (2016). Portfolio assessment as a window into reading development. International Journal of Foreign Language Teaching and research Volume 4, Issue 13, 11-18.

Hancock, C. R. (2006). Language teaching and language testing: A way and ways to make appropriate connections. In Accion Pedagogica No. 5, pp. 6-13.

Litbangkemdikbud. (2016, 616). Tentang PISA. Retrieved from Badan Penelitian dan Pengembangan Kementerian Pendidikan dan Kebudayaan: http://litbang.kemdikbud.go.id/index.php/surveiinternasional-pisa
Mullis, I. V., Martin, M. O., Foy, P., \& Drucker, K. T. (2012). PIRLS 2011 international results in reading. Boston, USA: TIMMS \& PIRLS International Study Center, Lynch School of Education, Boston College.

Progress in international reading literacy study. (2016, 6 16). Retrieved from National Center for Educational Statistics: https://nces.ed.gov/surveys/pirls/

Sağirli, M. (2016). Analysis of reading comprehension levels of fifth grade students who learned to read and write with the sentence method. Journal of Education and Training Studies Vol. 4 No. 2, 105-112.

Svinicki, M. D. (2004). Authentic assessment: Testing in reality. New Directions for Teaching and Learning, No. 100, 23-29.

Wiggins, G. (1998). Educative assessment: Designing assessments to inform and improve student performance. San Fransisco: Jossey-Bass. 